\title{
Bone formation with disruption of the lamina dura in the mandibular third molar
}

This article was published in the following Dove Press journal:

Clinical, Cosmetic and Investigational Dentistry

6 January 2010

Number of times this article has been viewed

\section{Minoru Yamaoka \\ Masahide Ishizuka \\ Masahiro Takahashi \\ Takashi Uematsu \\ Kiyofumi Furusawa}

Matsumoto Dental University, Oral and Maxillofacial Surgery,

Shiojiri, Nagano, Japan
Correspondence: Minoru Yamaoka Matsumoto Dental University, Oral and Maxillofacial Surgery, Shiojiri, Nagano 399-078I, Japan Fax +8I 263512076

Email yamaoka@po.mdu.ac.jp
Abstract: The lamina dura is a healthy structural component in teeth. This study highlights the association of bone formation with disruption of lamina dura below the crown of the mandibular horizontal incompletely impacted third molar.

Keywords: lamina dura, radiolucency, bone formation, mandible, third molar

Disruption of the lamina dura has been thought to occur at the beginning of periodontitis, but it is a complex issue in the field of dental practice. The lamina dura is observed as a thin radiopaque layer of dense bone around sound teeth in a normal dental arch, and is continuous with the shadow of cortical bone at the alveolar crest. ${ }^{1}$ The lamina dura is influenced by dental diseases and marked occlusion, ${ }^{1}$ and the presence of a radiographic crestal lamina dura is positively associated with clinical periodontal stability. ${ }^{2}$ The lamina dura is affected by not only odontogenic infections but also systemic diseases such as hyperparathyroidism, ${ }^{1,3}$ renal osteodystrophy, ${ }^{1,4}$ hypophosphatasia, ${ }^{1}$ and hypophosphatemia. ${ }^{1}$ Thus, although the state of the lamina dura could be valuable for diagnosis, identification of its disruption is frequently difficult because small variations and disruptions in its continuity may result from superimpositions of cancellous bone and small nutrient canals passing from the marrow spaces to the periodontal ligament. ${ }^{1}$

Moreover, changes in the lamina dura from a normal to distorted status cannot be frequently distinguished due to the subtle line between them, suggesting the necessity of using other signs and symptoms in the diagnosis. These results raise an additional complicating factor. Teeth with a lamina dura without radiolucency are seen as normal, especially in the young, teeth without a lamina dura with radiolucency are seen as showing periodontitis, and teeth with a lamina dura with radiolucency are seen as showing the progression of periodontitis. However, teeth without both a lamina dura and radiolucency are rarely seen except in tooth adhesion to bone. Teeth without both a lamina dura and radiolucency could be frequently seen below the crown of the mandibular horizontal incompletely impacted third molar in a previous study. ${ }^{5}$ Populations showing this finding were significantly older than those with a lamina dura without radiolucency in both genders, indicating that the lamina dura is disrupted with age. This serves as an explanation for several features of bone formation and cause of lamina dura disruption, and suggests a decrease in bone metabolism and/or the apoptosis of bone tissue. These may be explained by the effect of aging and chronic submit your manuscript | www.dovepress.com

Dovepress
Clinical, Cosmetic and Investigational Dentistry 20I0:2 I-3

(C) 20I0 Yamaoka et al, publisher and licensee Dove Medical Press Ltd. This is an Open Access article which permits unrestricted noncommercial use, provided the original work is properly cited. 


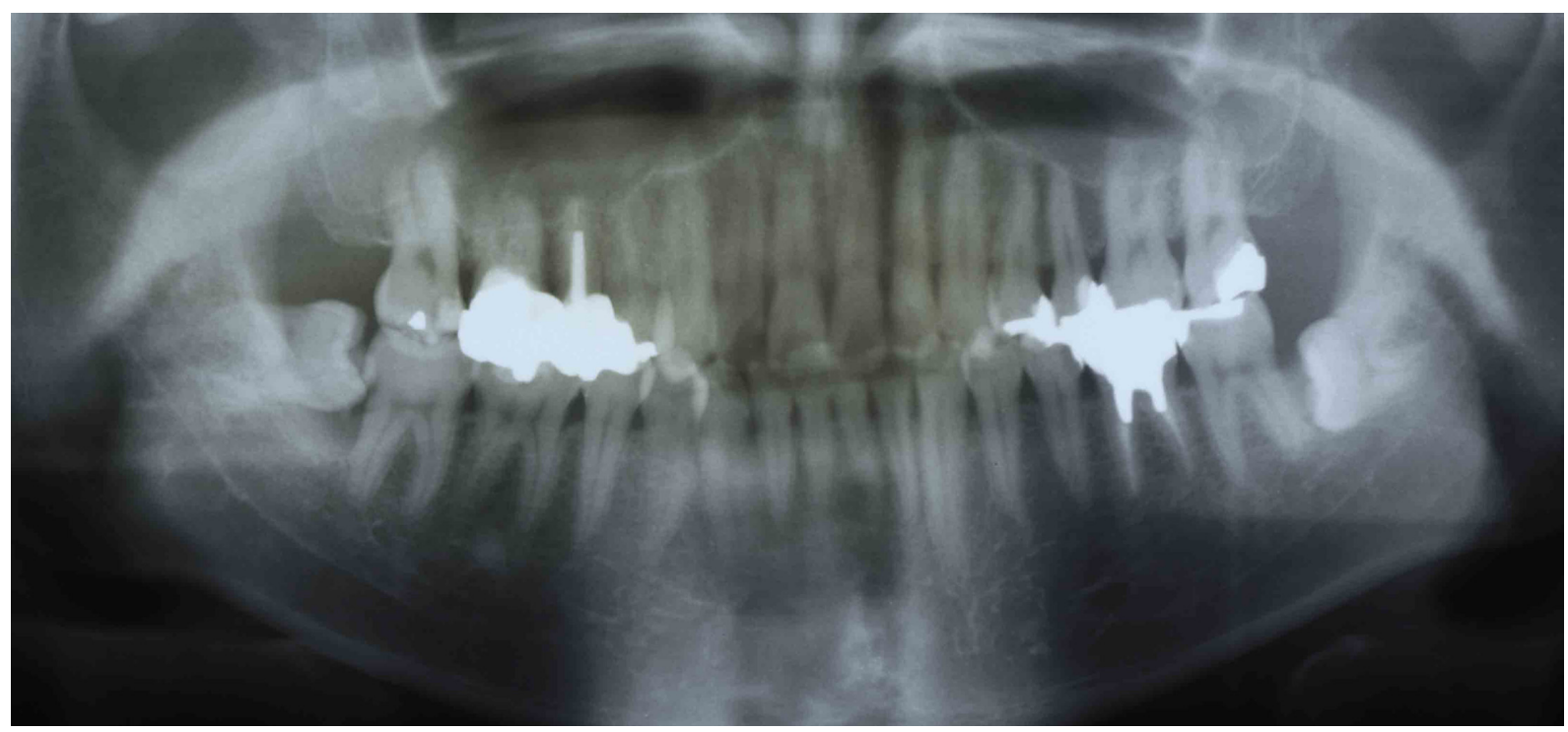

Figure I Showing a mandibular left horizontal incompletely impacted third molar without either the lamina dura or radiolucency below the crown in a 35 -year-old woman.

stimuli causing horizontal incomplete impaction. However, these explanations may contradict the phenomenon that bone develops a close contact with enamel of the crown as bone tissue fills the space between the lamina dura and crown. Although there is still considerable uncertainty regarding disruption of the lamina dura, it seems that the enamel allows neighboring healthy bone tissue to grow to closely contact it. These results suggest the environment is sufficient to grow bone tissue. A question arises as to which conditions favor bone growth, and drive or promote the acquisition of new bone. Moreover, the fact that the phenomena did not appear in the young but in the elderly is of particular interest. These findings allow us to ascertain the important role of enamel matrix protein for bone growth as a marker of conditional improvement, although little is known about the conditions that favorably allow normal bone tissue to grow at regulated levels attached to enamel in place of the lamina dura. Disruption of the lamina dura does not always impair its stability, but leads either to bone resorption or bone formation due to physiological mechanisms in the elderly. Enamel matrix derivatives (EMD) has been shown to promote periodontal regeneration. ${ }^{6}$ Hydroxyapatite absorbs calcium and tends to grow bone tissue, resulting in the close contact of bone with enamel, and matrix components in EMD may be responsible for the clinical effects, ${ }^{7}$ as the osteogenic effect of EMD in vivo, at least partly, involves mesenchymal cell growth and differentiation, ${ }^{8,9}$ and EMD has been shown to be present on treated root surfaces for up to four weeks following periodontal surgery. ${ }^{10}$ The activities of EMD are similar to those of parathyroid hormone (PTH), which acts anabolically to increase the cancellous bone mass, ${ }^{11}$ being supported by the reduction of the cortical bone thickness with an increase of tori in hyperparathyroidism reported by Padbury. ${ }^{3}$ Regarding our finding that enamel even in the elderly may promote bone formation, these responses of bone tissue may be related to enamel crystal changes on aging and maturation. ${ }^{12}$ These findings cannot be generalized to the lamina dura around the roots, which is surrounded with cement and the periodontal membrane.

Loss of the periodontal membrane and cement below the crown of mandibular horizontal incompletely impacted third molars indicates that the lamina dura below the crown is not included in ectomesenchymal but mesenchymal tissue, ${ }^{13}$ where basic fibroblast growth factor ${ }^{14}$ may exhibit only weak activities on the loss of the periodontal membrane.

Observation of the lamina dura may need to be revised to include age-related patterns to minimize the impact of the presence of the lamina dura with a healthy status, and the presence of radiolucency may need to be evaluated to decide the prognosis of disruption of the lamina dura, because its disruption showed a good prognosis for remaining teeth when radiolucency was absent below the crown of the mandibular horizontal incompletely impacted third molar. However, this knowledge does not apply to other teeth that have erupted normally.

\section{Disclosures}

The authors report no conflicts of interest in this work. 


\section{References}

1. White SC, Pharoah MJ. Oral Radiology: Principles and interpretation. 6th ed. St. Louis, MO: Mosby Elsevier; 2009.

2. Rams TE, Listgarten MA, Slots J. Utility of radiographic crestal lamina dura for predicting periodontitis disease-activity. J Clin Periodontol. 1994;21(9):571-576.

3. Padbury AD Jr, Tözüm TF, Taba M Jr, et al. The impact of primary hyperparathyroidism on the oral cavity. J Clin Endocrinol Metab. 2006;91(9):3439-3445.

4. Morii H, Okamoto T, Iba K, et al. Age-related changes of renal osteodystrophy. Endocrinol Jpn. 1979;26(Suppl):81-84.

5. Yamaoka M, Takahashi M, Ishihama K, Uematsu T, Furusawa K. Age-related disruption of lamina dura: evidence in mandibular horizontal incompletely impacted third molar. Clin Interv Aging. 2009;4:451-456

6. Gestrelius S, Andersson C, Johansson A, et al. Formation of enamel matrix derivative for surface coating; kinetics and all colonization. J Clin Periodontol. 1997;24(9Pt2):678-684.

7. Chong CH, Carnes DL, Moritz AJ, et al. Human periodontal fibroblast response to enamel matrix derivative, amelogenin, and platelet-derived growth factor-BB. J Periodontol. 2006;77(7):1242-1252.
8. Lyngstadaas SP, Lundberg E, Ekdahl H, Andersson C, Gestrelius S. Autocrine growth factors in human periodontal ligament cells cultured on enamel matrix derivative. J Clin Periodontol. 2001;28(2):181-188.

9. Reseland JE, Reppe S, Larsen AM, et al. The effect of enamel matrix derivative on gene expression in osteoblasts. Eur J Oral Sci. 2006;114(Suppl 1):205-211.

10. Sculean A, Windisch P, Keglevich T, Fabi B, Lundgren E, Lyngstadaas PS. Presence of an enamel matrix protein derivative on human teeth following periodontal surgery. Clin Oral Investig. 2002;6(3):183-187.

11. Reeve J, Bradbeer JN, Arlot M, et al. hPTH 1-34 treatment of osteoporosis with added hormone replacement therapy: biochemical, kinetic and histological responses. Osteoporos Int. 1991;1(3):162-170.

12. Wu Y, Ackerman JL, Kim HM, Rey C, Barroug A, Glimcher MJ Nuclear magnetic resonance spin-spin relaxation of the crystals of bone, dental enamel, and synthetic hydroxyapatites. J Bone Miner Res. 2002; 17(3):472-480.

13. Bosshardt DD, Schroeder HE. Cementogenesis reviewed: a comparison between human premolars and rodent molars. Anat Rec. 1996;245(2):267-292.

14. Blentic A, Tandon P, Payton S, et al. The emergence of ectomesenchyme. Dev Dyn. 2008;237(3):592-601.
Clinical, Cosmetic and Investigational Dentistry

\section{Publish your work in this journal}

Clinical, Cosmetic and Investigational Dentistry is an international, peer-reviewed, open access, online journal focusing on the latest clinical and experimental research in dentistry with specific emphasis on cosmetic interventions. Innovative developments in dental materials, techniques and devices that improve outcomes

\section{Dovepress}

and patient satisfaction and preference will be highlighted. The manuscript management system is completely online and includes a very quick and fair peer-review system, which is all easy to use. Visit http://www.dovepress.com/testimonials.php to read real quotes from published authors. 